\title{
Use of heat tolerance traits in discriminating between groups of sheep in central Brazil
}

\author{
Marlos Castanheira - Samuel Rezende Paiva - Helder Louvandini • Aline Landim • \\ Maria Clorinda Soares Fiorvanti • Bruno Stefano Dallago • Patricia Spoto Correa • \\ Concepta McManus
}

Accepted: 20 June 2010 /Published online: 23 July 2010

(C) Springer Science+Business Media B.V. 2010

\begin{abstract}
The animal and its environment make up an integrated system, where each acts on the other. Tropical regions are characterized by high levels of solar radiation and environmental temperature which may adversely affect animal production. This study carries out a multivariate analysis of physical and physiological traits in sheep in the Federal District of Brazil to test the ability to separate
\end{abstract}

\footnotetext{
M. Castanheira $\cdot$ A. Landim $\cdot$ M. C. S. Fiorvanti

Escola de Veterinária, Universidade Federal de Goiás, Goiânia, GO, Brazil

M. Castanheira

e-mail: castanheira_m@hotmail.com

A. Landim

e-mail: alinelandim@yahoo.com.br

M. C. S. Fiorvanti

e-mail: clorinda@vet.ufg.br

\author{
S. R. Paiva \\ EMBRAPA Recursos Genéticos e Biotecnologia, \\ Brasília, DF, Brazil
}

e-mail: samuel@cenargen.embrapa.br

H. Louvandini · B. S. Dallago · C. McManus $(\bowtie)$

Faculdade de Agronomia e Medicina Veterinária,

Universidade de Brasília,

Brasília, DF, Brazil

e-mail: concepta@unb.br

H. Louvandini

e-mail: hlouvand@unb.br

B. S. Dallago

e-mail: brunodallago@yahoo.com.br

\section{P. S. Correa}

Secretaria de Vigilância em Saúde, Ministério da Saúde, Brasília, DF, Brazil

e-mail: Patricia.Louvandini@saude.gov.br
}

groups of animals and determine which traits are most important in the adaptation of animal to heat stress. The variables studied included coat thickness, number and length of hairs, pigmentation of the skin and coat, number of sweat glands as well as heart and respiratory rates, rectal and skin temperatures, sweating rate, and blood parameters. Five groups of ten animals were used depending on breed (Bergamasca, crossbred, or Santa Inês) or coat color (Santa Inês-brown, white, and black). The data underwent multivariate statistical analyses including cluster, discriminate, and canonical, using Statistical Analysis System$\mathrm{SAS}^{\circledR}$. The tree diagram showed clear distances between groups studied and canonical analysis was able to separate individuals in groups, especially Bergamasca and white Santa Inês. The canonical correlation redundancy analysis showed that coat reflectance as well as hair length and number of hairs per unit area were the most useful in explaining changes in physiological traits. Skin and coat traits such as hair length, coat reflectance, percentage of epithelial area occupied by sweat glands, skin reflectance and thickness, as well as heart and breathing rates were the most important in separating these groups.

Keywords Adaptation - Canonical analysis - Discriminant . Ewes $\cdot$ Temperature

\section{Introduction}

Brazil's center-west region lies in the tropical region and is responsible for most of its ruminant production at pasture (Mariante et al. 2008). Tropical regions can be characterized by high levels of solar radiation and temperature which adversely affect animal production when compared with animals in temperate zones (McManus et al. 2009b). The 
animal is considered to be stressed when it has to alter its physiology and behavior to adapt to adverse environmental and management conditions. This adaptation involves a series of neuroendocrinological, physiological, and behavioral responses which act to equilibrate animal functions (Marai et al. 2007).

In tropical and subtropical regions heat stress can affect growth, development, food, and water intake as well as reproduction function in particular embryo development and gestation (Silva 2000). The maintenance of body temperature within physiological limits is necessary for the animal to remain healthy, survive, and maintain its productivity and longevity (Marai et al. 2007). Animals should, therefore, be selected to be able to produce in these environments (Starling et al. 2002).

Evaluations of adaptability to hot environments have been carried out using physiological adaptation tests involving respiration, heartbeat, and body temperature (Baccari Junior 1989). Quesada et al. (2001) showed that it was necessary to know the tolerance and adaptive capacity of various breeds as a technical basis for sheep exploration in a certain region, including direction of crossbreeding programs.

In some species, color differences between phenotypes appear to be an important factor influencing body temperature (Silva et al. 2003). Skin pigmentation is necessary to protect deep tissues against excess exposure to solar shortwave radiation in tropical zones. Light coats have been considered as the most desirable ones for livestock in tropical areas (McManus et al. 2009a) as dark-coated animals tend to acquire greater heat loads from solar radiation than light-colored ones (Bianchini et al. 2006).

It has also been shown that size, shape, and surface area are important morphological traits in body thermal balance (Marai et al. 2007). Small animals that have proportionately large surface area can be more vulnerable to environmental temperatures. Protective properties depend on the morphological characteristics of the skin (color, thickness, sweat glands, etc.) and of the hair coat (especially the thickness of the coat, number of hairs per unit area, diameter of the hairs, length of the hairs, and angle of the hairs to the skin surface), which allow the animal to exchange heat with the environment through radiation, convection, evaporation, and conduction (Silva 2000).

The animal's response to heat stress has been measured by variations in the body temperature, respiratory rate and heart rate, as well as sweating rate. These result in changes in blood parameters as heat stress increases considerably water and ion losses of ruminants (Beede and Collier 1986) as well as increases plasma and extracellular volume. Heat stress also leads to activation of heat loss mechanisms, dissipating heat to the environment and reducing the production of metabolic heat (Silvanikove 2000).
Many traits can be measured to determine heat tolerance of a breed and therefore there is a need to examine the usefulness of measuring these traits useful for characterization and at the same time are reliable breed discriminants. Methods of statistical multifactoral discriminant analysis do not limit the amount of monitored variables, and at the same time confirm the discriminatory capacity of each variable (Herrera et al. 1996).

The Brazilian sheep herd is comprised of approximately 14 million head and the center-west region maintains approximately 7\% of these animals (Instituto 2008), mainly composed of hair and semi-woolen sheep. While the size of the national herd has increased 3\% in the last 10 years, in this region the increase was $37 \%$. This increase has meant that several breeds and crosses are being used in the region with little quantitative information on their production or adaptation traits. Most of these animals originated from the Santa Inês breed which itself has been the target of indiscriminate crossing in recent years, thereby affecting its rusticity and heat tolerance.

Physiological mechanisms which limit and adjust cold and heat tolerance are regaining interest due to global warming. Shifts in the geographical distribution of animals have also stimulated actions within the Food and Agricultural Organization of the United Nations (Pilling et al. 2008) to attempt to standardize descriptors for animals and their environments. This study aimed to carry out a multivariate analysis of physical and physiological traits measured in different genetic groups of sheep to determine which traits were important in differing between the groups in terms of heat adaptation.

\section{Material and methods}

The data for this study was collected in the Sheep Management Center of the University of Brasília, localized at $15^{\circ} 47^{\prime} \mathrm{S}$ and $47^{\circ} 56^{\prime} \mathrm{W}$ Gr., in the Federal District, Brazil. Morphological and physiological data were collected on 50 adult female non-lactating and non-pregnant sheep from five different groups (ten animals per group), including Santa Inês hair sheep (three groups with white (WSI), brown $(\mathrm{BrSI})$, or black (BISI) coat), Bergamasca (B-a white Italian wool breed), and crosses between black Santa Inês and Bergamasca (SIB) which were brown in color with residual wool. The animals were kept on Andropogon gayanus pasture with a mineral mixture.

The traits measured included: coat thickness, density, reflectance, and length and skin reflectance and number of sweat glands per area of skin; heart and breathing rate, rectal and skin temperature, sweating rate, and blood parameters. Coat thickness was measured using an adipometer in $1 / 10$ of millimeter. Reflectance was measured 
using a reflectometer (Silva 2000) where reflected light is captured by a light sensitive photoresister and registered in amperes (A). This gives an indirect reading of skin and coat pigmentation. Hairs were collected in a $1 \mathrm{~cm}^{2}$ region of the upper shoulder, counted, and measured using a paquimeter.

Skin fragments were collected in the upper part of the shoulder using a biopsy punch with a $1 \mathrm{~cm}$ internal diameter, after application of a local anesthetic (lidocaine cloridrate $2 \%$ ). These were fixed in formaldehyde and processed in histotechnique (omadm-20), dehydrated in increasing concentrations of ethanol $(70 \%, 90 \%$, and $100 \%$ ), diaphanized in xylol, and infiltrated in liquid paraffin. This was then cut in $4 \times 4-\mu \mathrm{m}$ thick sections using a microtome (Leica model RM 2025) for slide mounting and colored with hematoxylin and eosin.

An AxioSkop (Zeiss) microscope coupled with a CCD digital color camera (Sony model DXC-107) and computer with board for digital capture Pixel View Play TV (320× 240 pixels) for image capture. Four secretor portions of the sweat glands were visualized and measured per slide. Measurements were taken using a program for morphological measurements (Image-Pro Plus ${ }^{\circledR}$ version 5.0, Media Cybernetics, L.P.).

The following parameters were measured: sweating rate (SR), using the method proposed by Berman (1957), modified by Schleger and Turner (1965), respiratory rate (RR), heart rate (HR), rectal (RT), and skin temperature (ST). RR and HR were measured using a stethoscope. RT was measured with a digital thermometer introduced into the animal's rectum. ST was measured on a shaved area near the 12th vertebra of the animal using an infrared thermometer Raytek PhotoTemp ${ }^{\mathrm{TM}} \mathrm{MX}^{\mathrm{TM}}$.

Blood was collected by venipuncture using vacutainer tubes with EDTA when the physiological traits were measured. The number of erythrocytes (Hem), leukocytes (Leu), and the concentration of hemoglobin $(\mathrm{Hb})$ and were carried out in a semi-automatic cell counter (CC550, Cellm ${ }^{\mathrm{TM}}$ ). The hematimetric parameters (mean corpuscular volume- $\mathrm{MCV}$ and mean corpuscular hemoglobin concentration-MCHC) were determined by calculation.

Packed cell volume (PCV in \%) was determined using capillary tubes in microhematocrit centrifuge. The concentration of total plasma proteins (TPP in $\mathrm{g} / 100 \mathrm{~mL}$ ) was determined using a refractometer and the plasma retained in a capillary tube.

Analysis of variance of the data can be found in McManus et al. (2009b) and McManus et al. (2010). Data was collected at 2 p.m. after $2 \mathrm{~h}$ exposure to the sun. Mean temperature was $27^{\circ} \mathrm{C}$ and humidity $70 \%$.

After standardization, multivariate analyses were carried out using Statistical Analysis System-SAS ${ }^{\circledR}$ (SAS Institute. User's Guide. Version 9. Cary 1999), in accordance with Sneath and Sokal (1973), to place animals in groups in accordance with their degree of similarity and verify discriminatory capacity of the original traits in the formation of these groups.

These procedures included correlations between physical and physiological traits (CORR), principal component analysis to attempt to understand the sources of variation in the data (PRINCOMP), organize information about variables so that relatively homogeneous groups, or "clusters", were formed (CLUSTER), and see distances between these groups (TREE), use the characteristics to predict the group to which a given unit belongs (DISCRIM), select a subset of the quantitative variables for use in discriminating among the groups (STEPDISC), and summarize between-class variation in much the same way that principal components summarize total variation (CANCORR).

\section{Results}

The data in Table 1 is a summary of that published by McManus et al. (2009b) and McManus et al. (2010), with means, coefficients of variation, and standard deviations of the traits measured. The tree diagram (Fig. 1) for all traits shows two distinct groups, one formed by black, brown, and white Santa Inês sheep and the other by Bergamasca and crossbreds. The black and brown sheep were closely linked while the white were more distant. When the physical factors were studied by themselves (Fig. 2), the tree diagram for these traits was similar to that found for all traits. The Bergamasca formed a group by themselves as they are larger animals than the other groups studied. Mean weights per group were 50.2, 47.3, 46.4, 46.1, and $45.9 \mathrm{~kg}$ for Bergamsca, crossbred, black, brown, and white Santa Inês, respectively.

The discriminant canonical analysis (Fig. 3) showed an overlay of brown, black, and crossbred animals while Table 2 shows the variation for each canonical variable, where the Bergamasca showed the highest variation followed by the black SI animals. The crossbreds and white animals showed the lowest variation. Mean canonical variables per group are in Fig. 4 with the Bergamasca were separated from the other groups.

Figure 5 shows canonical means for morphological and physiological traits used to separate the groups in this study. Heart rate, sweating rate, and mean corpuscular volume did not show much discriminatory value in this case. The canonical correlation redundancy analysis (not shown) showed that coat reflectance as well as hair length and number of hairs per unit area were the most useful in explaining changes in physiological traits. The other parameters analyzed had a better discriminatory power especially hair length, hemoglobin concentration as well as coat and skin reflectance (Table 3). 
Table 1 Means, coefficients of variation, and standard deviations of traits measured in sheep

\footnotetext{
${ }^{a}$ Standard deviation

${ }^{\mathrm{b}}$ Coefficient of variation (\%)
}

\begin{tabular}{llccc}
\hline Traits & & Mean & $\mathrm{SD}^{\mathrm{a}}$ & $\mathrm{CV}^{\mathrm{b}}$ \\
\hline Coat reflectance (A) & $\mathrm{CR}$ & 7.7 & 1.1 & 14.6 \\
Skin reflectance (A) & $\mathrm{SkR}$ & 7.1 & 1.0 & 13.6 \\
Skin thickness (mm) & $\mathrm{STH}$ & 4.9 & 0.8 & 15.7 \\
Hair length $(\mathrm{cm})$ & $\mathrm{HL}$ & 3.2 & 3.6 & 112.9 \\
Number of hairs $/ \mathrm{cm}^{2}$ & $\mathrm{NH}$ & 310 & 770 & 23 \\
Sweat gland area $(\%)$ & Area & 22 & 5 & 24 \\
Heart rate $\left(\right.$ beats $\left./ \mathrm{minute}^{2}\right)$ & $\mathrm{HR}$ & 99 & 19 & 19 \\
Respiratory rate $(\mathrm{breaths} / \mathrm{minute})$ & $\mathrm{RR}$ & 43 & 19 & 44 \\
Rectal temperature $\left({ }^{\circ} \mathrm{C}\right)$ & $\mathrm{RT}$ & 39.8 & 0.8 & 2.0 \\
Skin temperature $\left({ }^{\circ} \mathrm{C}\right)$ & $\mathrm{ST}$ & 36.5 & 1.9 & 5.2 \\
Sweating rate $\left(\mathrm{gm}{ }^{-2} \mathrm{~h}^{-1}\right)$ & $\mathrm{SR}$ & 193 & 119 & 62 \\
Packed cell volume $(\%)$ & $\mathrm{PCV}$ & 28 & 7 & 24 \\
Total plasma protein $(\mathrm{g} / 100 \mathrm{~mL})$ & $\mathrm{TPP}$ & 6.8 & 0.9 & 13.6 \\
Erythrocytes $\left(\times 10^{6} / \mathrm{mm}^{3}\right)$ & $\mathrm{Hem}$ & 10.2 & 2.8 & 27.4 \\
Hemoglobin $(\mathrm{mg} / 100 \mathrm{~mL})$ & $\mathrm{Hb}$ & 9.1 & 2.0 & 21.5 \\
Leukocytes $\left(\times 10^{3} / \mathrm{mm}^{3}\right)$ & $\mathrm{Leu}$ & 13.1 & 4.6 & 35.3 \\
Mean corpuscular volume (fl) & $\mathrm{MCV}$ & 29.9 & 6.3 & 21.1 \\
Mean corpuscular hemoglobin concentration $\%$ & $\mathrm{MCHC}$ & 31.1 & 6.0 & 19.1 \\
Mean corpuscular hemoglobin & $\mathrm{MCH}$ & 0.90 & 0.11 & 12.52 \\
\hline & & & &
\end{tabular}

The simple discriminant analysis showed that the traits that most influenced group separation were hair length $\left(R^{2}=94 \%\right)$, coat reflectance ( $\left.83 \%\right)$, percentage of epithelial area occupied by sweat glands $(37 \%)$, skin reflectance $(30 \%)$ and thickness $(28 \%)$, leukocytes $(20 \%)$, as well as heart $(13 \%)$ and breathing $(13 \%)$ rates. All other traits had $R^{2}$ lower than $10 \%$. In five of the ten comparisons made, skin reflectance appeared as a significant discriminant variable, followed by coat reflectance in four comparisons.

Table 4 shows that in general $100 \%$ of the animals were correctly classified in their genetic groups by the analyses used except the brown and black animals which were $70 \%$ and $81 \%$, respectively.

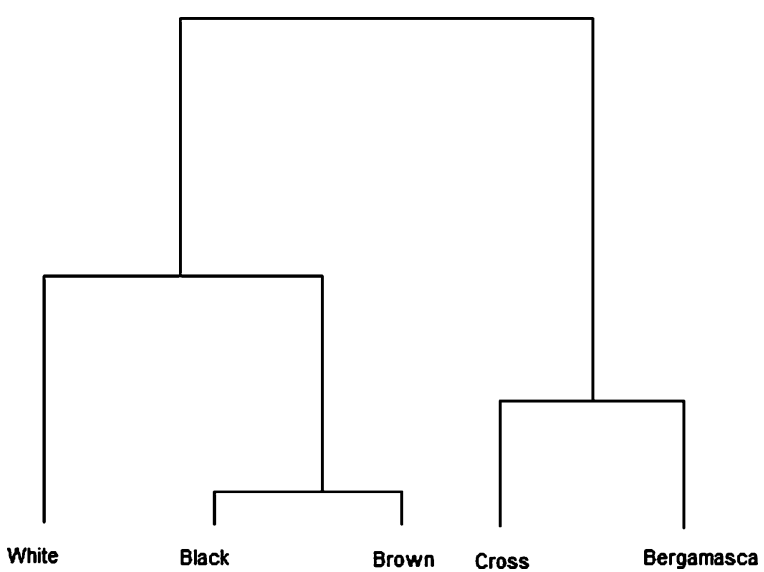

Fig. 1 Dendrogram of morphological and physiological factors affected by heat stress in sheep

\section{Discussion}

Various authors have used multivariate analyses to analyze distance between breeds based on morphological traits in sheep and goats, including Herrera et al. (1996), Dossa et al. (2007), and Traoré et al. (2008). In the present study, these analyses are used to discriminate between types of sheep based on characteristics cited in the literature as affecting heat tolerance.

The tree diagram for physical traits showing the Bergamasca in a group by themselves may be due to the fact that they are larger animals than the other groups studied. This is in

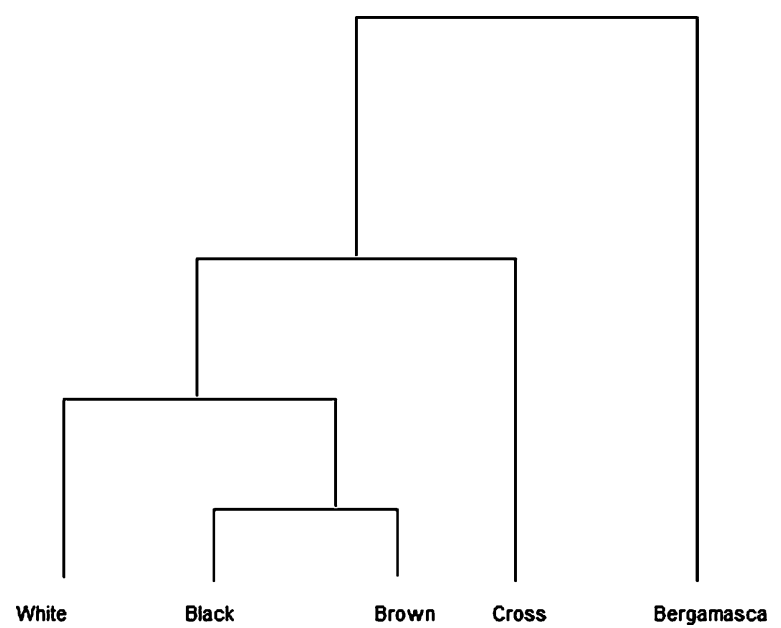

Fig. 2 Dendrogram of breed morphological factors affected by heat stress in sheep 
Fig. 3 Graphic representation of canonical analysis of individuals in each group of sheep studied

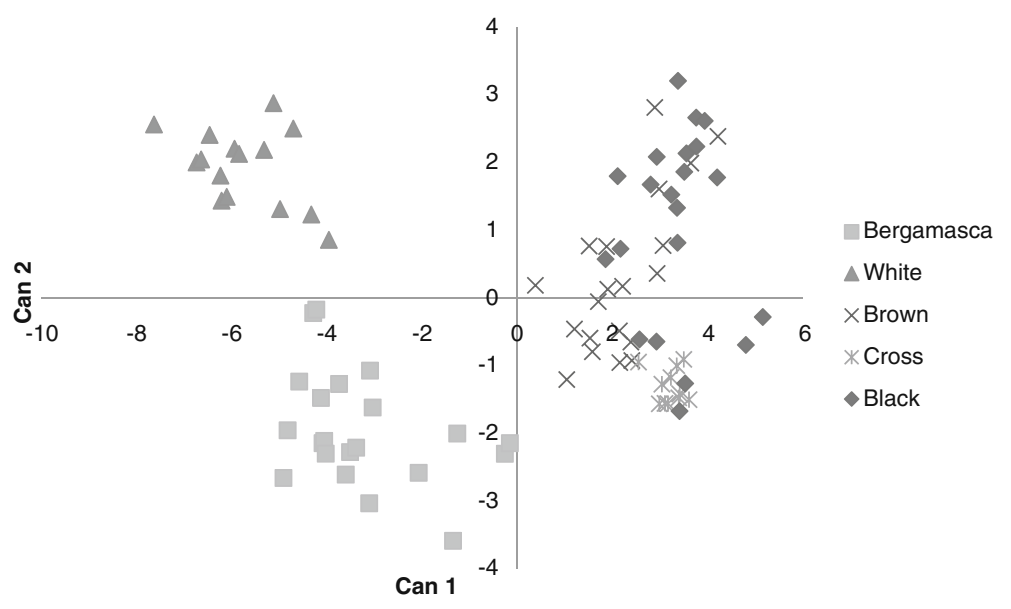

agreement with Bianchini et al. (2006) who stated that heavier animals had lower surface area to lose heat. These animals had longer, coarser hairs (as well as wool) which retained more air between the skin and environment also making loss of heat more difficult. A greater number of hairs also make heat loss more difficult as seen by Gebremedhin et al. (1997). When there are fewer hairs per surface area, the wind can penetrate the coat more easily removing trapped air, thereby favoring thermal transfer. The crossbreds were also separated from the other groups as had several morphological traits similar to Bergamasca.

The origin of the Santa Inês sheep is still somewhat unclear. While recent studies have shown some introgression between Santa Inês, Bergamasca, and other wool breeds in recent years (Paiva et al. 2005) to increase meat production potential, the breed formation is likely due to crossing of several hair and wool breeds found in the Northeast of Brazil, followed by selection for lack of wool. The breed was officially created in 1977, englobing crossbred animals with varying phenotypes. In a study in Merino sheep, Renieri et al. (2008) showed dominance with complete penetrance of: (1) full white coat over pigmented, (2) black coat over brown, and (3) uniform coat over spotted pattern. If this is true for hair sheep, then the increases of predominance for black and brown Santa Inês is the result of active selection against coat color.

The black and brown animals were closest on the tree diagram, probably due to the higher amount of melanin in

Table 2 Variance of canonical variables for groups of sheep

\begin{tabular}{lccc}
\hline Group & Can 1 & Can 2 & Total \\
\hline Bergamasca & 1.40 & 0.83 & 2.23 \\
Black Santa Inês & 0.81 & 1.40 & 2.21 \\
Brown Santa Inês & 0.91 & 1.15 & 2.06 \\
White Santa Inês & 0.99 & 0.56 & 1.55 \\
Crossbred & 0.30 & 0.24 & 0.54 \\
\hline
\end{tabular}

the skin and coat of these animals, separating them from the white animals. Dyce et al. (1996) showed that skin and coat color depends in part on the presence of pigment granules in certain component cells which protect the animal against ultraviolet radiation, which in part explains why skin and hair color is important in heat adaptation of animals in tropical countries. According to Maia et al. (2003), the number of pigmented hairs per unit area is important in protecting the skin against ultraviolet radiation but this may cause heat increase in these animals.

McManus et al. (2009b) studied these traits and observed that Santa Inês animals with white coat were better adapted to tropical climates. These animals had thinner skin, shorter hairs, and with less pigmentation in the coat and skin. The brown Santa Inês was the least well adapted in the previous study and had thicker skin, longer hairs, and fewer sweat glands.

Maia et al. $(2003,2005)$ noted that hair length and thickness were important traits in animal adaptation in the tropics with a decreasing adaptation with increasing hair length. Short, shiny, fine hair led to better heat dissipation while long coarse hair led to lower heat exchange with the environment, as with the Bergamasca animals evaluated here. The Bergamasca and crossbreds were grouped together probably due to the presence of wool or its residue, and the genetic link between the two groups.

The white Santa Inês were separated from the other groups and shown to be better adapted to heat stress (McManus et al. 2009b) with lower heart and breathing rates as well as lower rectal temperature. This may be due to higher reflectance of the coat with lower thermal radiance absorbance. The results found by these authors suggest that coat color is more important than skin color in terms of heat stress.

Pereira (2005) stated that light coats (white or cream) were more efficient in reflecting radiation especially higher wave lengths. Other authors such as Silva (2000), Gebremedhin and Wu (2002), and Pereira (2005) also stated that animals with more pigmented skin were more 
Fig. 4 Mean canonical variables per genetic group

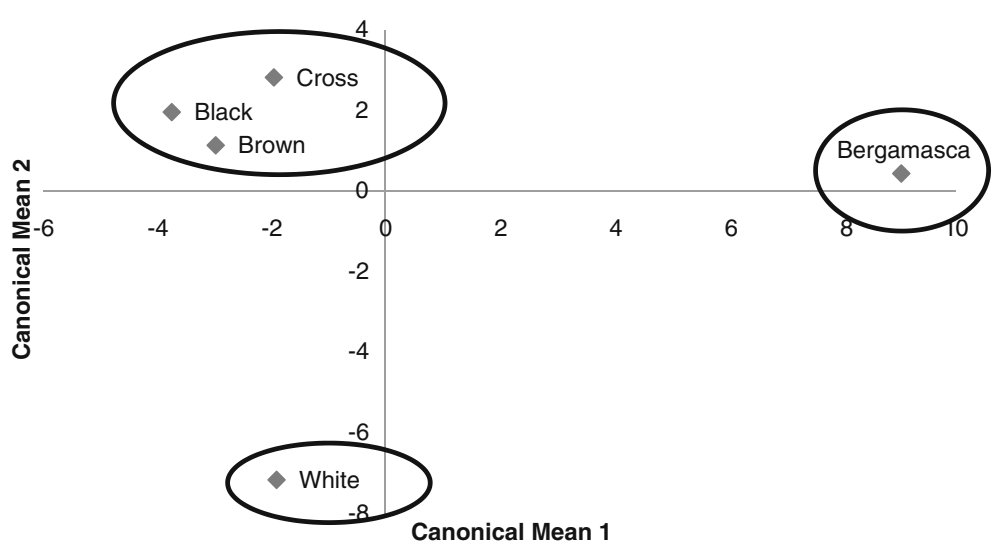

resistant to ultraviolet rays but absorbed more thermal energy, increasing surface skin temperature causing more heat stress. This probably affected physiological parameters in the dark-coated sheep in this experiment. It should be noted that, unlike tropical cattle, in these sheep a lightcolored coat is not accompanied by a dark-colored skin.

The discriminant canonical analysis may be explained by the origin of the brown, black, and crossbred animals. According to Paiva et al. (2005), the Santa Inês in the Northeast and Center west of Brazil are divided in two subpopulations with different genetic standards. Crosses between original Santa Inês and animals of the Suffolk breed were carried out in the Northeast to improve growth rate and carcass conformation. These crosses were then backcrossed to give rise to the black and brown animals which predominate the Santa Inês breed today, while the white animals are genetically closer to the original native breed. This may also explain the better heat tolerance in this group of animals. The Bergamasca also formed a distinct group. The first two canonical variables explained $93 \%$ of the variation with the first explaining $81 \%$.

The variation for each canonical variable is shown in Fig. 3, where the Bergamasca showed the highest variation followed by the black SI animals. The crossbreds and white animals showed the lowest variation. Mean canonical variables per group are in Fig. 4. The Bergamasca were separated from the other groups, probably due to poorer heat adaptation due to presence of wool, and higher stress reactions as shown in McManus et al. (2009b).

Heart rate, sweating rate, and mean corpuscular volume did not show much discriminatory value in this study. MCV defines the volume of red blood cells in the animal and is used to classify anemia in animals (Feldman et al. 2000). Heart rate may be affected by other factors as well as temperature, such as management stress. Kolb (1980) and Reece (1988) showed that variables such as respiratory rate and heart rate are good indicators of health status but to be interpreted correctly factors such as species, exercise, physiological state, excitability, and environment should be taken into consideration.

Sweating rate needs more studies in sheep as wool or longer hair may affect evaporation. According to Silva (2000) wool sheep lack convection close to the skin which affects sweat evaporation. Maia et al. (2009), studying temperature effects and air movement, both natural and artificial, in fleece of sheep using a climatic chamber, found that the fleece is not efficient in thermal isolation or heat loss.
Fig. 5 Graphical representation of canonical means for morphological and physiological traits in sheep. Abbreviations are in Table 1

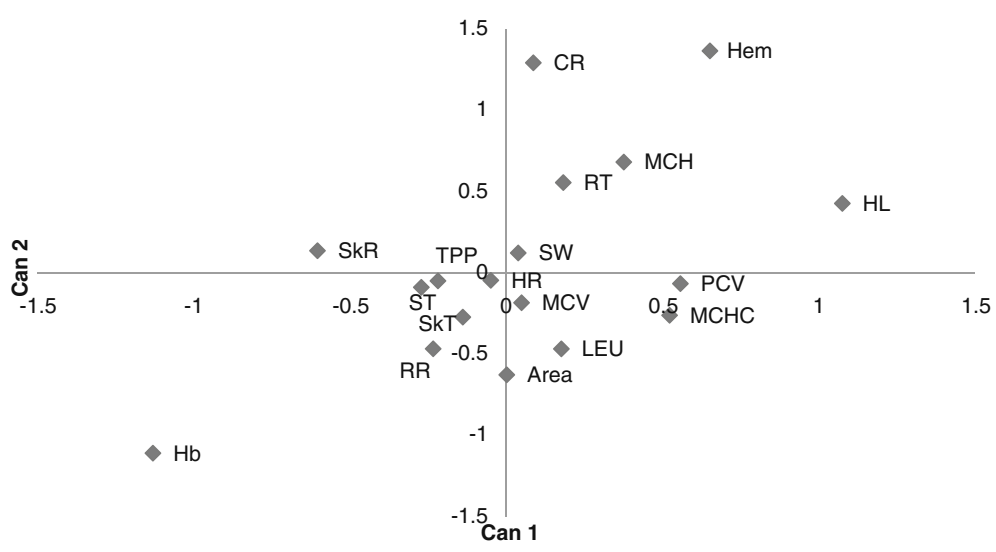


Table 3 Discriminant analysis traits examined for heat tolerance in sheep

\begin{tabular}{llllc}
\hline & Brown & Black & White & Bergamasca \\
\hline Crossbred & Area, STH, & ST, RT, & CR, MCH, & SkR, ST, \\
& MCH & NH, SkR & HR, NH & $\begin{array}{c}\text { Hb, Hem, } \\
\text { area }\end{array}$ \\
& & & & SkR, VCM, \\
Brown & & CR, ERY, & CR, SkR, & RT, MCHC, \\
Santa Inês & & SkR, STH, & & SR \\
& & & CR, SR, & SkR, ST, \\
Black & & HR & area, TPP \\
Santa Inês & & & & STH, MCH, \\
White & & & PCV \\
Santa Inês & & & & \\
\hline
\end{tabular}

Abbreviations are in Table 1

The other parameters analyzed had a better discriminatory power especially hair length, hemoglobin concentration as well as coat and skin reflectance. Interpretation of these results should be made with caution. Cunningham (2004) stated that physiological alterations are organic attempts of the animal to leave the stressed condition in which it finds itself and is dependent on specific conditions at the time of measurement.

The traits that most influenced group separation were hair length, coat reflectance, percentage of epithelial area occupied by sweat glands, skin reflectance and thickness, leukocytes, as well as heart and breathing rates. The fact that in five of the ten comparisons made, skin reflectance appeared as a significant discriminant variable, followed by coat reflectance in four comparisons shows the importance of these traits in maintaining heat balance in sheep.

These variables have been shown to be related to heat tolerance in other studies such as Silva (2000) and Pereira (2005), where animals with thicker hairs and denser coats have more difficulty in releasing heat. The blood traits such as number of leuckocytes and red blood cells as well as total plasma protein may be altered by dehydration caused by the increased breathing rate according to Garcia-Navarro

Table 4 Percentage of animals classified in each genetic group

\begin{tabular}{lccccc}
\hline From group & Bergamasca & White & Brown & Crossbred & Black \\
\hline Bergamasca & 100 & 0 & 0 & 0 & 0 \\
$\quad$ White & 0 & 100 & 0 & 0 & 0 \\
$\quad$ Santa Inês & & & & & \\
$\quad$ Brown & 0 & 0 & 70 & 0 & 30 \\
$\quad$ Santa Inês & 0 & 0 & 0 & 100 & 0 \\
$\quad$ Crossbred & 0 & 0 & 14 & 5 & 81 \\
$\quad$ Black Santa & 0 & 0 & 0.3 & 0 & 0.2 \\
$\quad$ Inês & 0 & 0.2 & 0.2 & 0.2 & 0.2 \\
Error level & 0.2 & & & & \\
Prior & &
\end{tabular}

and Pachaly (1994), Silva (2000), Pereira (2005), and Erickson and Poole (2006).

The discriminant analysis managed to correctly classify animals in their groups. The errors found with the brown and black animals, and the fact that the animals in these two groups were generally placed in the other, was possibly due to the closeness of physical and physiological traits as well as their historical origin as described above.

\section{Conclusion}

Canonical analyses showed distinct grouping of the animals involved for heat tolerance. Skin and coat traits were the most important in separating these groups while coat reflectance as well as hair length and number of hairs per unit area were the most useful in explaining changes in physiological traits.

Acknowledgments The authors would like to thank Finatec, FAPDF, and $\mathrm{CNPq}$ (INCT) for financial assistance and scholarships during this study.

\section{References}

Baccari Junior, F. 1989. Mecanismos adaptativos de ovinos lanados nos trópicos. In: Simpósio Paulista de Ovinocultura, Fundação Cargill, p. 18-21

Beede, D.K. and Collier, R.J., 1986. Potential nutritional strategies for intensively managed cattle during heat stress. Journal of Animal Science, 62, 543-550

Berman, A. 1957. Influence of some factors on the relative evaporative rate from the skin of cattle. Nature, 179,1256

Bianchini, E., McManus, C., Lucci, C. M., Fernandes, M. C. B., Prescott, E. Mariante, A. S., Egito, A. A. 2006. Características corporais associadas com a adaptação ao calor em bovinos naturalizados brasileiros. Pesquisa Agropecuária Brasileira, v, 1443-1448

Cunningham, J.G. 2004. Tratado fisiologia veterinária. 3ed Rio de Janeiro: Guanabara Koogan, 579p.

Dossa, L. H., Wollny, C., Gauly, M. 2007. Spatial variation in goat populations from Benin as revealed by multivariate analysis of morphological traits, Small Ruminant Research, 73, 150-159

Dyce, W. M., Sack, W.O., Wensing, C. J. C. 1996. Tratado de anatomia veterinária. $2^{\mathrm{a}}$ ed. Rio de Janeiro:Guanabara Koogan. $663 \mathrm{p}$

Erickson, H. H., Poole, D. C. 2006. Fisiologia do exercício. In: REECE, W.O.. Dukes Fisiologia dos animais domésticos. 12 ed. Rio de Janeiro: Guanabara Koogan.

Feldman, B.F.; Zinkl, J.G.; Jain, N.C. (Eds.). 2000. Schalm's veterinary hematology. 5.ed. Philadelphia: Lippincott Williams \& Wilkins, $1344 \mathrm{p}$

Garcia-Navarro, C. E. K., Pachaly, J. R. 1994. Manual de hematologia veterinária. São Paulo: Varela, 163p.

Gebremedhin, K. G., Ni, H., Hillman, P.E. 1997. Temperature profile and heat flux through irradiated fur layer. In: International Livestock Environment Symposium, p. 226-233.

Gebremedhin, K.G., Wu, B. 2002. Simulation of sensible and latent heat losses from wet-skin surface and fur layer. Journal of Thermal Biology, 27, 291-297 
Herrera, M., Rodero, E., Gutierrez, M. J., Peña, F., Rodero, J. M. 1996. Application of multifactorial discriminant analysis in the morphostructural differentiation of Andalusian caprine breeds, Small Ruminant Research, 22, 39-47

Instituto FNP, 2008. Anuário da pecuária brasileira: ANUALPEC. São Paulo: Instituto FNP, 291p

Kolb, E. 1980. Coração e circulação. In: Fisiologia veterinária. 4.ed. Rio de Janeiro: Guanabara Koogan, p. 293-294

Maia, A. S. C., Silva, R. G., Andrade, P. C. 2009. Efeitos da temperatura e da movimentação do ar sobre o isolamento térmico do velo de ovinos em câmara climática. Revista Brasileira de Zootecnia, 38, 104-108

Maia, A.S.C., Silva, R.G., Bertipaglia, E.C.A. 2003. Características do pelame de vacas Holandesas em um ambiente tropical: um estudo genético e adaptativo. Revista Brasileira de Zootecnia, $32,843-853$

Maia, A.S.C., Silva, R.G., Bertipaglia, E.C.A. 2005. Environmental and genetic variation of the effective radiative properties of the coat of Holstein cows under tropical conditions. Livestock Production Science, 92, 307-315

Marai, I., El-Darawany, A., Fadiel, A., Abdel-Hafez, M. 2007. Physiological traits as affected by heat stress in sheep-A review. Small Ruminant Research, 71, 1-12

Mariante, A.S., McManus, C., Mezzadra, C., Rovere, G., Euclides,K. 2008. Development of production systems in South America: beef production in the southern cone and its impact on the global market. Animal Production and Animal Science WorldwideWAAP Book of the year 2007, 264p.

McManus, C., Prescott, E., Paludo, G.R., Bianchini, E., Louvandini, H., Mariante, A.S. 2009a. Heat tolerance in naturalized Brazilian cattle breeds. Livestock Science, 120, 256-264

McManus, C., Paludo, G.R., Louvandini, H., Gugel, R., Sasaki, L. C. B., Paiva, S. R. 2009b. Heat Tolerance in Naturalized Brazilian Sheep: Physiological and Blood Parameters. Tropical Animal Health and Production, 41, 95-101

McManus, C.; Sasaki, L. C. B.; Lucci, C. M.; Gugel, R.; Corrêa, M. P. C.; Louvandini, H. (2010). Skin and Coat Traits in Sheep in Brazil and their Relation with Heat Tolerance. Tropical Animal Heath Production. doi:10.1007/s11250-010-9663-6

Paiva, S. R., Silvério, V. C., Egito, A. A., Mcmanus, C., Faria, D. A., Mariante, A. S., Castro, S. R., Albuquerque, M. S. M., Dergam,
J. A. 2005. Genetic variability of the Brazilian hair sheep breeds. Pesquisa Agropecuária Brasileira, 40, 887-893

Pereira, C.C.J. 2005. Fundamentos de bioclimatologia aplicados à produção animal. Belo Horizonte: FEPMVZ, 195p

Pilling, D., Rischkowsky, B., Scherf, B. (Eds). 2008. Report of the FAO/WAAP Workshop on Production Environment Descriptors for Animal Genetic Resources, 97p.

Quesada, M., McManus, C. and Couto, F.A.D., 2001. Heat tolerance of two hair sheep breeds in the Federal District, Brazil, Revista Brasileira Zootecnia, 30, 1021-1026

Reece, W. O. 1988. Respiração nos mamíferos. In: Dukes, H. H.; Swenson, M. J. Fisiologia dos animais domésticos. 10 ed. Rio de Janeiro: Guanabara Koogan, p. 199-205

Renieri, C., Valbonesi, A., La Manna, V., Antonini, M., Lauvergne, J. J. 2008. Inheritance of coat colour in Merino sheep, Small Ruminant Research, 74, 23-29

SAS Institute. User's Guide. Version 9. Cary: 1999. 295p.

Schleger, A.V., Turner, H.G. (1965) Sweating rates of cattle in the field and their reaction to diurnal and seasonal changes. Aust J Agric Res 16:92-106

Silva, R. G. 2000. Introdução à bioclimatologia animal. São Paulo: Nobel, 2000, 286 p.

Silva, R.G. N., La Scala Jr., N., Tonhati, H. 2003. Radiative properties of the skin and haircoat of cattle and other animals, Transactions of the ASABE, 46, 913-918

Silvanikove, N., 2000. Effects of heat stress on the welfare of extensively managed domestic ruminants, Livestock Production Science, 67, 1-18

Sneath, P. H.; Sokal, R. R. 1973. Numerical taxonomy: The principles and practice of numerical classification. San Francisco: W. H. Freeman, 1973. 573p.

Starling, J. M. C., Silva, R. G., Cerón-Muñoz, M., Barbosa, G. S. S. C., Paranhos da Costa, M. J. R. 2002. Análise de algumas variáveis fisiológicas para avaliação do grau de adaptação de ovinos submetidos ao estresse por calor, Revista Brasileira Zootecnia, 31, 2070-2077

Traoré, A., Tamboura, H. H., Kaboré, A., Royo, L. J., Fernández, I., Álvarez, I., Sangaré, M., Bouchel, D., Poivey, J. P., Francois, D., Toguyeni, A., Sawadogo, L., Goyache, F. 2008. Multivariate characterization of morphological traits in Burkina Faso sheep, Small Ruminant Research, 80, 62-67 